\title{
NURSES' WORK IN INTENSIVE CARE UNITS: FEELINGS OF SUFFERING
}

\author{
Júlia Trevisan Martins \\ Maria Lúcia do Carmo Cruz Robazzi
}

Martins JT, Robazzi MLCC. Nurses' work in intensive care units: feelings of suffering. Rev Latino-am Enfermagem 2009 janeiro-fevereiro; 17(1):52-58.

The purpose of this study was to investigate the feelings of suffering that Intensive Care Unit (ICU) nurses experience, and the strategies they use to face these feelings. It is a descriptive study using a qualitative approach and based on content analysis. The study used previous studies on Work Psychodynamics as complementary groundwork. Data collection occurred by means of semi-structured interviews, which were transcribed, categorized, and subcategorized. Results showed that suffering is related to: taking care of a young patient in critical condition, taking problems home, the patient's family, the team's work, and technology at work. As for the defense strategies used, emphasis is given to the search for strength in religion, promoting inter-relationships among team members, engaging in physical activity, and withdrawing from the patient.

DESCRIPTORS: stress; psychological; intensive care units; worker's health

\section{EL TRABAJO DEL ENFERMERO EN UNA UNIDAD DE TERAPIA INTENSIVA: SENTIMIENTOS DE SUFRIMIENTO}

El presente estudio tuvo como objetivo investigar los sentimientos de sufrimiento en el trabajo de enfermeros de una Unidad de Terapia Intensiva y las estrategias usadas para enfrentar esos sentimientos. Consiste en un estudio descriptivo, con abordaje cualitativo, teniendo como eje conductor el análisis de contenido y, como soporte complementar, los estudios de la Psicodinámica del Trabajo. Los datos fueron recolectados por medio de entrevistas semiestructuradas, transcritas, clasificados en categorías y subcategorías. Los resultados demostraron que las vivencias del sufrimiento están relacionadas con: el cuidar del paciente crítico joven, llevar los problemas para casa, la familia del paciente, el trabajo en equipo, la falta de reconocimiento del trabajo realizado y la tecnología en el trabajo. Con relación a las estrategias defensivas utilizadas, se destaca la búsqueda de fuerzas en la religión, la promoción de relaciones entre los miembros del equipo, la realización de actividades físicas, y el alejarse del paciente.

DESCRIPTORES: estresse psicológico; unidades de terapia intensiva; salud del trabajador

\section{O TRABALHO DO ENFERMEIRO EM UNIDADE DE TERAPIA INTENSIVA: SENTIMENTOS DE SOFRIMENTO}

O presente estudo objetivou investigar os sentimentos de sofrimento no trabalho de enfermeiros de Unidade de Terapia Intensiva e as estratégias usadas para enfrentarem esses sentimentos. Consiste em estudo descritivo, com abordagem qualitativa, tendo como eixo condutor a análise de conteúdo e, como suporte complementar, os estudos da Psicodinâmica do Trabalho. Os dados foram coletados por meio de entrevistas semi-estruturadas, transcritas, categorizadas e subcategorizadas. Os resultados demonstraram que as vivências do sofrimento estão relacionadas com cuidar do paciente crítico jovem, levando os problemas para casa, a família do paciente, o trabalho em equipe, a falta de reconhecimento do trabalho realizado e a tecnologia no trabalho. Com relação às estratégias defensivas utilizadas, há destaque para a busca de força na religião, promoção de interrelacionamento entre os membros da equipe, realização de atividade física e afastamento do paciente.

DESCRITORES: estresse psicológico; unidades de terapia intensiva; saúde do trabalhador

\footnotetext{
${ }^{1}$ Assistant Professor at Universidade Estadual de Londrina, Brazil, Doctoral student at Escola de Enfermagem de Ribeirão Preto, da Universidade de São Paulo, Centro Colaborador da OMS para o Desenvolvimento da Pesquisa em Enfermagem, Brazil, e-mail jtmartins@uel.br; ${ }^{2}$ Full Professor at Escola de Enfermagem de Ribeirão Preto, da Universidade de São Paulo, Centro Colaborador da OMS para o Desenvolvimento da Pesquisa em Enfermagem, Brazil, e-mail avrlmccr@eerp.usp.br.
} 


\section{INTRODUCTION}

$\boldsymbol{R}$ eflecting on suffering as something pertaining to the work of Intensive Care Unit (ICU) nurses requires understanding of the situations these professionals experience, due to their work density and rhythm, by the diversity of technology employed, by the constant responsibility of this job, which often does not finish when the work shift ends, and, therefore, can lead to levels of suffering that are greater than one can imagine.

Work in the ICU is complex because patients are considered critical and present an imminent life risk. Nurses deal with difficulties related to the technical complexity of patient care, and are exposed to the high-maintenance demands of patients, their families, doctors, and institutions, all of which can cause feelings of suffering within them ${ }^{(1)}$.

In view of the technological devices in the ICU and the great amount of procedures which patients there are submitted to, the environment is recognized as one of the most traumatizing and aggressive, from the user's viewpoint as well as from that of service providers. Furthermore, the stress applied to the health team, due to the constant presence of death, favors the feeling of suffering ${ }^{(2)}$.

Working with suffering, pain, and witnessing death can lead nurses towards growing work-related stress. It is also a fact that care delivery to critical patients, who can have a constantly unstable clinical condition, is a factor that triggers weariness and, consequently, causes suffering ${ }^{(3)}$.

Though work may be seen as a source of suffering, it is still important in life. It is understood not only as a form of subsistence, but also as being intrinsically related to social status. In nursing, it has a direct relationship with the activities developed by the nursing team, the task division level by categories, ill individuals, death, accelerated work rhythm, and others.

Comprising a large part of one's everyday life, work can be the genesis of fulfillment and pleasure, the way one develops individually and collectively, which is essential for balance and growth and makes it possible to maintain one's health. At the same time, it can be the source of physical, psychological and cognitive weariness, of suffering, tension, anguish, and stress ${ }^{(4)}$.

If work is considered the central point of both pleasure and suffering, it is often difficult to find pleasure in work when one is surrounded by suffering. For this reason, it is essential to unveil these feelings and seek alternatives to ameliorate or minimize the harmful effects of negative feelings.

Hence, the purpose of this study is to investigate the feelings of suffering that ICU nurses experience, and the defense strategies these workers use to deal with those feelings.

The study aim, therefore, was to offer elements to make changes that could have positive repercussions on these nurses' lives, in the institution they work in, and in their personal relationships; there is also an expectation to share the obtained results with other professionals, seeking alternatives to minimize or overcome the feelings of suffering that appear in the ICU work environment.

\section{THEORETICAL FRAMEWORK}

This framework was founded on Work Psychodynamics studies, based on the reality of workers' situations and the understanding that work and man are not rigid; rather, they are in constant motion and are therefore flexible and dynamic ${ }^{(5)}$.

Work Psychodynamics seeks to change the experience of suffering, through the process of transformation. When suffering can have its meaning redefined, i.e. changed into creativity, it becomes beneficial to man's identity, since it provides an increased defense against the dangers of physical and mental unbalance. In this way, work becomes a form to balance health, but the opposite can also occur, making health more fragile, i.e., it becomes pathogenic suffering. This occurs when there is no more room for freedom and flexibility in work organization, nor for changes, nor an effort to listen to workers $^{(6)}$.

The visible stability of the man-work relationship is directly linked to the free and open balance of evolution and change, a constant equilibrium in permanent motion. If it is refrained, blocked, extended or permanent, stability leads to production inefficiency, and at any moment may cause rupture. In this manner, psychodynamics analyzes the dynamics of the mental processes through the act of the individual's confrontation with his or her reality ${ }^{(5-6)}$.

It is the process of confronting singular history, beliefs, desires, and the meaning of life, all 
constructed based on the singularities of each man. The world is seen as objective, with tasks to be completed. It is in the subject's reason and power to permit suffering to be related, and to search to make work the mediator of peace ${ }^{(7)}$.

For work to be the mediator of pleasure, workers should use defense strategies that stem from the conflict between the work organization and mental functioning, recognized as a source of suffering. These strategies are mechanisms by which workers seek to change, transform, and minimize their perception of the reality that causes them suffering. It is usually an internal process for individuals, since they often cannot change the pressure imposed by the work $\operatorname{organization}^{(6,8)}$.

The defense strategies can be used individually or collectively. Individual strategies consist of a personal mental process and exists regardless of the presence of the object that generated the conflict. Collective strategies, on the other hand, are characterized by the presence of external conditions that generate suffering and are constructed by establishing rules and consensus from workers ${ }^{(6)}$. When defense strategies are used, whether they are individual or collective, workers are searching for a way to protect themselves from the high level of suffering at work, so that they may continue working $^{(8)}$.

Though strategies are important, they can have consequences in the sense that they change one's perception of reality, favoring workers' alienation and creating obstacles in their battle against the undesirable pressures from the work organization. Hence, the challenge of psychodynamics is directly linked to the actions that can change the fate of suffering and favor transformation ${ }^{(6)}$.

\section{METHODOLOGY}

A qualitative research approach was used. The inclusion criteria established for this study were the following: nurses who have been actively employed for at least one year, who were working at the time of data collection, and agreed to participate in the study. Nurses were excluded if they were on vacation or leave.

The total number of nurses to be interviewed was not determined a priori because, in qualitative research, data collection continues until there are enough convergences to define the study phenomenon. Saturation of the contents that emerge from the discourse ensures that the information is diversified and broad regarding the reconstitution of the object in the study material, thus confirming the overall formation $^{(9)}$. In this study, data saturation was achieved with eight interviews obtained from nurses who worked day, evening and night shifts.

Data collection was performed between January and March 2007 by means of semi-structured interviews, using guiding questions and a taperecorder to ensure the reliability of recorded answers. The tapes were then fully transcribed. The guiding questions were: - have you ever experienced, or are you currently experiencing suffering at work in the ICU? - What feelings? - How do you deal with these feelings?

Content analysis was used to analyze the data identified by the guiding questions. It is understood as a set of communication analysis techniques, with the purpose to obtain, through systematic and objective procedures to describe message contents, the indicators that permit researchers to deduce the knowledge regarding the production and reception conditions of these messages ${ }^{(10)}$.

The analysis had three stages: pre-analysis, material exploration, and result treatment. In this type of analysis, semantic cuts are used to compose the record and context units. These cuts originate from the analytic categories, which are understood to be a statement about an issue, a phrase, a compound phrase, or a phrase synthesized by the influence from which it is possible to cover a large group of individual formulations ${ }^{(10)}$.

The research project was approved by the University Hospital Research Ethics Committee and the interviewees signed the Free and Informed Consent Form.

A code $(E 1, E 2$...) was established to preserve anonymity and symbols like [...] were used to inform that part of the speech was omitted, and [ ] for pauses in the statements.

\section{RESULTS AND DISCUSSION}

The analysis of the interviews yielded two analytic categories, the first related to suffering at work and the second to the defense strategies, both including subcategories. 
The first category, which addresses ICU nurses' suffering at work, emerged from the following subcategories.

Suffering with the young critical patient and taking problems home

The nurses' feelings of suffering, in which the perspective of death as a finitude is inevitable, as well as the suffering related to the attachments established with the patients were identified in the following statements.

[...] younger patients' death is suffering, it is too difficult to accept the death of an adolescent (E6).

[...] unable to let go, so during my colleague's shift I call to know how the patient is. I take it home [...] (E3).

Young people's death is not seen as a natural process; rather, there is an expectation that we are born, grow up, and live for a lengthy number of years. Death is better accepted when there is a feeling that the person has completed his or her stages in life.

In a study performed with the purpose of understanding the experiences of ICU nurses, the results showed that, for these professionals, the death of younger patients and children is stronger than the emotional control of the whole team, i.e. everyone suffers ${ }^{(11)}$.

In the statement by E3, it is obvious that the nurse knows that it is wrong to take ICU issues home but, despite the clear need to 'let go' and try to reduce excessive involvement, the established links are still very strong.

Perhaps the attachment to patients is related to their hospitalization time in the unit, because they often stay for a long period of time and thus permit nurses to form a stronger bond. This fact is important towards more humanized care, but limits should be established; when a strong attachment is created, nurses run the risk of additional suffering.

The established attachments can be correlated to the humanistic aspect, characteristic of nursing, creating the need for dedication, consideration, involvement and abnegation, but also generating feelings of suffering in view of the fragileness of the patients, especially those in critical condition $^{(12)}$.

Suffering with the critical patient's family

The statements given in the interviews show there is suffering concerning family members, since they recognize they (the family members) are suffering for a loved one, and identify themselves with it, as revealed in the following statement.

To know what that person means to the family [...] the more you get involved with the patients' history, the more it affects you emotionally and the more you get involved in the history, the more you suffer (E2).

When looking after the patient, ICU nurses interact a great deal with their family members, and they become close; involvement goes beyond the patient.

When the nurses identify with the relatives, feeling what they feel or feeling pity for the patients they look after, they feel incapable because they are not able to help due to their own personal limitations, or because there are situations when nothing else can be done, so that feelings of suffering are experienced $^{(13)}$.

Suffering of working in a team

There are feelings of suffering when working as a team, as shown below.

$[\ldots .$.$] it generates suffering, anxiety, when there is a lack$ of responsibility from someone in the team. The team notices that [...] it has a negative effect on the rest of the team (E7).

Nursing demands collectivity, cooperation, commitment, responsibility and other traits, especially in ICUs, which, due to the patients' severity, demands the ability to handle highly complex equipment, make constant clinical evaluations, perform actions in an accelerated work rhythm, perform complex procedures, and make immediate decisions, most of the time $e^{(1,14)}$.

In ICUs, activities are so intense that it is essential to have a united, harmonious, and committed team offering quality care, and there must be a solid base for constructive communication, friendship, and mutual respect ${ }^{(14)}$.

The difficulties of team work should be discussed and shared, so that it is possible to establish better integration and, consequently, reap the benefits for the team, patient, family, institution, and others.

Suffering related to alternating shifts and absenteeism

It was found that there are feelings of suffering when there are alternating work shifts and absenteeism, as reported in the statements.

Having to alternate shifts, it wears us out, [...] day routine is one thing, night shift is another (E7). 
[...] too many employees miss work, absenteeism is high [...] so this part is very wearing (E1).

Alternating shifts are considered unsatisfactory since team members have only a cordial relationship, with no sense of cooperation between them. The quality of care and of interpersonal relationships is only possible if there is real proximity, i.e. working together.

When it is impossible to keep the team integrated, due to alternating shifts and employee absenteeism, it becomes difficult to establish any common ground that would contribute to better social relationships, and this can create suffering ${ }^{(6)}$.

Absenteeism is worrisome because it disorganizes work, causing dissatisfaction and overload among workers, reducing the quality of the care rendered to patients ${ }^{(15)}$.

Lack of appreciation at work

Not being appreciated by colleagues for the work done is seen as a lack of understanding, causing suffering. The following statement shows such a situation.

[...] what makes me suffer sometimes is change of shift, because in the morning you pass your patients on to your nurse colleague, you spent twelve hours there, $[. .$.$] you make the$ decisions and then in the morning people are very clear in saying - couldn't you have done this? Why didn't you do this way? Wouldn't the patient be better now? [ ] whatever you do, your colleagues never appreciate it [...] (E5)

Appreciation is the process of valuing the effort and suffering invested in performing work, which makes it possible for subjects to construct their identity, i.e. experiencing satisfaction and self fulfillment ${ }^{(16)}$.

In Work Psychodynamics, identity construction mobilizes the process of symbolic retribution, of recognizing the worker's singularity from the other, through the contributions he or she makes to the work organization ${ }^{(7)}$.

\section{ICU Technology}

The results showed that nurses suffer, wear out, become anguished and are frightened by the existing equipment, since it does not supply the patients' needs as shown in the statement below.

[...] there is state-of-the-art equipment next to obsolete equipment that has been here since the ICU opened [...] so I feel fear and anguish because I have experienced equipment jams with patients at an imminent death risk if you don't answer in time [] the alarm sometimes doesn't work, so we are always alert (E6).

Common work situations are permeated with unexpected happenings, jams, incidents, function anomalies, organization incoherence, and incidents involving the material, instruments, machines, and also the workers themselves. Hence, there is discrepancy between what is prescribed and the reality of the situation, and there is no way to foresee the gap between reality and what is prescribed, and this can cause feelings of suffering for the worker ${ }^{(4,7)}$.

The second category that identified the defense strategies used by ICU nurses was identified through subcategories, presented below.

Seeking strength in religion

Belief, faith, and prayer are methods nurses use to deal with the difficulties that cause suffering, as stated below.

[... I pray a lot, I ask the Divine Holy Spirit to give me strength (E3).

I see prayers, belief and faith as a strategy, a relief valve (E6).

Attachment to religiosity and the search for support in superior "entities", or the belief in something supreme, helps nurses cope with the feelings of suffering caused by the difficult situations they face ${ }^{(13)}$.

These relief valves are important in everyday life; however, they should be identified as such by the workers, because if they are used as the only alternative and in an individual manner only, they may cause alienation from the rest of the team.

Promoting interrelationships among team members

The importance that nurses assign to having good interpersonal relationships, through which they establish friendship and trust, relieve tension, and offer mutual support, which promotes dialogue and encourages individuals to perform to their highest potential, is shown in the following statement.

Just because I'm in charge does not mean that I don't have to keep our dialogue, between the employee and me [...], joking a little, relaxing, and in this way treat the relationship in the best possible way, so that friendships are built, we relax, talk about everything [...] we have parties (E4).

When there are moments that give the group strength, team work, friendship, and companionship, this is important because these moments allow for 
sharing experiences and knowledge, and help establish trust among team members.

In order to learn about the individuals' and the group's characteristics, it is necessary to create moments to unwind and possibilities for workers to express their feelings, needs, difficulties, doubts and concerns, so that solidarity is maintained in a calm and non-threatening manner ${ }^{(1,7)}$.

Engaging in physical activities

Physical activities, such as walking and attending a health club, are forms of stress reduction, as shown in the statements below.

[...] so what I do everyday is I practice some physical activities, [...] it reduces my stress (E2).

I go to the gym, I try to walk too, because it calms me down and reduces my stress (E7).

Physical activity contributes to people's quality of life. Among the important contributions to mental health in the short term, the highlights are on the reduction of stress and anxiety and, in the long term, there are positive changes in moderate depression, and on one's mood and self-esteem ${ }^{(17)}$.

Withdrawing from the patient and relative

One defense strategy that nurses use to avoid or reduce suffering is to withdraw from the patient when there is no more hope of survival, and they try to not get overly or deeply involved with the relatives so they can avoid suffering with them, as shown in the statements.

That's my strategy [] as the patient gets worse I also move away (E1).

[...] I don't let myself get too much involved with the family [...] I don't mix things because it is too much suffering (E8).

When facing patients with an imminent death, nurses distance themselves emotionally. This can happen because they are not emotionally well prepared to deal with death, and also because the undergraduate nursing courses focus on saving lives, curing, preventing, and promoting health.

It is so painful for nurses to work in situations that sometimes become unbearable, especially when it comes to being intimately involved with patients and their families, creating the need for defense strategies, such as escaping and withdrawing to reduce their own suffering ${ }^{(4)}$.

\section{CONCLUSIONS}

The nurses' statements express feelings of suffering at work regarding young critical patients, the fact that many take problems home, becoming involved with the patients' relatives, team work, alternating work shifts and absenteeism, and ICU technology.

The feelings of suffering that originate from these factors demonstrate the difficulties that nurses deal with at work, which can affect the care rendered to patients and their families, as well as the mental health of these professionals.

As to the individual defense strategies, nurses reported searching for strength in religiosity, engaging in physical activities, and withdrawing from patients and their relatives.

Defensive strategies are essential to protect oneself against suffering but, when used collectively, they can strengthen the team through the process of bonding among workers, because work should not be merely a task, but rather a common life experience of facing the resistance to reality, and assigning meaning to work, the situation, and suffering ${ }^{(18)}$.

The study identified the net effects of feelings of suffering and the defense strategies used by ICU nurses, not as a postulate of an experimental science searching for pure results, but as an interpretative science in search of meanings.

The results contributed to the work space itself on one hand, by reaffirming the dynamics of the mental/suffering process and, on the other hand, to the social value that provided man the strength to deal with the adversities at work and grow as a worker and person.

The feelings of suffering that were identified in this study reflected the reality of the situation because they originated at work itself, but there appears to be a naturalization of this feeling, as if it could not be surpassed and, therefore, is considered inherent to the profession and accepted as such.

There are methods for workers to deal with the suffering experienced in their work site, as each human has his or her own beliefs, culture, meaning of life, and other factors which influence them. However, that does not mean that one is free from searching, reflecting, and trying, collectively, to find new ways to organize work, so that men are not only a set of insurmountable rules, in which the only aim is to justify one's own behaviors. 
It is necessary to awaken in the workers a stronger recognition of their feelings and of their own existential life in the world. In order to achieve this, new skills and new consciousness must be created; that is, new beings capable of being at the same time as having. In this way, they will be able to take better care of their mental and physical health. This is a direct act of responsibility for these individuals, and an indirect act for the people and the institution around them.

These study results are in agreement with another study performed with ICU nurses, in which the stress level was related to factors like patient death, feelings of devaluation, lack of strength, errors they made, and others ${ }^{(19)}$. Another study developed with nurses working in oncologic units evidenced that the death of children and adolescents, problems related with the work team, and lack of personnel were situations perceived as stressful for the nurses, and the most commonly used coping strategy was positive reevaluation, problem solving, and selfcontrol $^{(20)}$.

Finally, it is emphasized that, despite its limitations, such as the subjectivity expressed by researchers and each nurse's particular interpretation of ICU work, this study showed some paths that have been formed and could certainly contribute to reaffirm and compare with previous studies regarding the same theme, as well as to bring new knowledge to light.

\section{REFERENCES}

1. Shimizu HE. As representações sociais dos trabalhadores de enfermagem não enfermeiros (técnicos e auxiliares de enfermagem) sobre o trabalho em unidades de terapia intensiva em um hospital escola. [tese]. São Paulo (SP): Escola de Enfermagem da Universidade de São Paulo/USP; 2000 .

2. Martins Jj. O Cotidiano de Trabalho de Enfermagem em UTI: prazer e sofrimento? [dissertação]. Florianópolis (SC): Escola de Enfermagem da Universidade Federal de Santa Catarina; 2000.

3. Santos JM, Oliveira EB, Moreira AC. Estresse fator de risco para a saúde do enfermeiro em Centro de Terapia Intensiva. Rev Enferm UERJ 2006; 14(4):580-5.

4. Dejours C. A loucura do trabalho: estudo da psicopatologia do trabalho. São Paulo (SP): Cortez; 1992.

5. Dejours C. Por um novo conceito de saúde. Rev Bras de Saúde Ocupacional 1986; 14(54):7-11.

6. Dejours C, Abdouchelli E. Desejo ou motivação? A interrogação psicanalítica sobre o trabalho. São Paulo (SP): Atlas; 1994.

7. Dejours C. Subjetividade, trabalho e ação. Rev Produção $2004 ; 14(3): 27-34$.

8. Lancman S, Sznelwar LI. Christophe Dejours: da psicopatologia à psicodinâmica do trabalho. Rio de Janeiro (RJ): Fiocruz; 2004.

9. Minayo MCS. O desafio do conhecimento: pesquisa qualitativa em saúde. Rio de Janeiro (RJ): Hucitec-Abrasco; 1993.

10. Bardin L. Análise de Conteúdo. Lisboa: Edições 70; 2004.
11. Figueiredo MRB, Stein AT. Vivências da enfermeira no trabalho em equipe em terapia intensiva: uma visão fenomenológica. Rev Arquivos Médicos 2004; 7(2):29-42. 12. Borsoi ICF. Saúde mental e trabalho: um estudo de caso da enfermagem. [dissertação]. Campinas (SP): Escola de Psicologia da Universidade Católica de Campinas; 1992.

13. Melo CCCP. Vivências de enfermeiras diante da dor, sofrimento e morte no seu cotidiano de trabalho. [dissertação]. Ribeirão Preto (SP): Escola de Enfermagem de Ribeirão Preto/ USP; 2000.

14. Leite MA, Vila VSC. Dificuldades vivenciadas pela equipe multirpofissional de terapia intensiva. Rev Latino-am Enfermagem 2005; 13(2):145-50.

15. Silva DM, Marziale MHP. Absenteísmo de trabalhadores de enfermagem em um hospital universitário. Rev Latino-am Enfermagem 2000; 8(5):44-51.

16. Mendes AM. Psicodinâmica do trabalho: teoria, método e pesquisas. São Paulo (SP): Casa do Psicólogo; 2007.

17. Secretaria de Políticas de Saúde/MS (BR). Projeto promoção da saúde. Programa nacional de promoção da atividade física "Agita Brasil": atividade física e sua contribuição para a qualidade de vida. Rev Saúde Pública 2002; 36(2):254-6.

18. Dejours C. A Banalização da Injustiça Social. $3^{a}$ ed. Rio de Janeiro (RJ): FGV; 2000.

19. Cavalheiro NA, Moura Junior DF, Lopes AC. Stress in nurses working in intensive care units. Riv Latino-am Enfermagem 2008; 16(1):29-35.

20. Rodrigues $A B C$, Correa E. Stressing and coping strategies used by oncology nurse. Riv Latino-am Enfermagem 2008; $16(1): 22-48$. 